\title{
Potential Influences of RNF6 on Prognosis and Metastasis of Colorectal Cancer: A Clinical Analysis [Retraction]
}

Zhu H, Wang C. Onco Targets Ther. 2020;13:2031-2036.

At the request of the author, the Editor-in-Chief and Publisher of OncoTargets and Therapy wish to retract the published paper.

The author, Huili Zhu, notified the journal that they used the name and email address of the corresponding author, Chunhui Wang, without their permission and the corresponding author had no knowledge of the publication. The experimental data presented in the published paper was also used without the proper consultation or permission of the data owners.
The Editor has determined the findings of the paper are unreliable and has agreed with the authors request to retract the article.

The author wished to apologise for this error.

Our decision-making was informed by our policy on publishing ethics and integrity and the COPE guidelines on retraction.

The retracted article will remain online to maintain the scholarly record, but it will be digitally watermarked on each page as "Retracted".

\section{Publish your work in this journal}

OncoTargets and Therapy is an international, peer-reviewed, open access journal focusing on the pathological basis of all cancers, potential targets for therapy and treatment protocols employed to improve the management of cancer patients. The journal also focuses on the impact of management programs and new therapeutic agents and protocols on patient perspectives such as quality of life, adherence and satisfaction. The manuscript management system is completely online and includes a very quick and fair peer-review system, which is all easy to use. Visit http://www.dovepress.com/ testimonials.php to read real quotes from published authors. 